\title{
BACHELOR'S AND MASTER'S DEGREES INTEGRATED IN PORTUGAL IN THE AREA OF COMPUTING: A GLOBAL VISION WITH EMPHASIS ON PROGRAMMING UCS AND PROGRAMMING LANGUAGES USED
}

\author{
Sónia Rolland Sobral ${ }^{1}$ \\ ${ }^{1}$ Universidade Portucalense (PORTUGAL) sonia@upt.pt
}

\begin{abstract}
The creation and maintenance of courses (1st cycle and integration 1st and 2nd cycle) in computer science is of concern to those responsible. The area is in constant development and, despite the need for very specialized technicians and almost unemployment zero, it seems that it is not in the minds of most students who finish high school.
\end{abstract}

This article describes how secondary education works in Portugal, as well as the entrance to the Portuguese higher education.

With this study we were able to verify which courses have the most demand and, on the other hand, those that do not constantly fill all the vacancies. In this study we verified that in the year 2016-2017 the students who intend to join the upper insino had 122 courses: 106 Lic-10 cycle, 15 Integrated Masters and 1 Preparation. In other words, the choice was made from the Area of Technologies and returned links to information about 193 courses. We extract courses in which in its denomination it had the content comput * and informát *. We also added eight that seemed relevant to us as Management and Information Systems or information technologies. The basis of our study consists of a 122 courses of 66 different intuitions. We highlight the institutions of higher education (public and private), denomination of courses and type (1st cycle, integrated masters or preparation). From these courses we verify the proofs of access are (with view to numerous clausulus).

The private Universities give little information: so we put them way out; for the rest: only 59 courses filled all the vacancies. We will study these 59 courses in more detail: institutions and different names. Of these, only 46 have course unity are available on-line. We have studied in detail the curricular units of the first two semesters. We extract the number of course unit and programming languages (which are) and study those course unity contents.

Of the 46 courses we presented we extracted ten, the top 10. The choice of these and not others is related to the number of places being higher than the other courses, as well as the entry notes. From this 10 courses we will study course plans, as well as giving emphasis to course unity those who use programming languages: what programming languages, paradigms, and how many are used.

In this way we get an overview of the curricula of computer courses in Portugal, namely what refers to paradigms and programming languages?

Keywords: Computer curriculum, computer languages, university.

\section{INTRODUCTION}

The creation and maintenance of courses (1st cycle and 1st and 2nd cycle integration) in informatics is a reason for concern for those responsible. The area is in constant development and despite the need for highly skilled technicians and almost zero unemployment, it seems that it is not in the minds of most students who finish high school.

Admission to higher education in Portugal is done by access with number clausulus: after 12 years of teaching, students have to take two exams in the 11th year and two exams in the 12th year to complete upper secondary education. Universities have a limited number of places and can define the formula with which students are serialized. Often this formula is $60 \%$ of the average higher education $+40 \%$ of the math exam of the 12 th grade, for example.

The teaching of programming and the programming languages in the first contact continues to be a concern of teachers and course coordinators. Often this decision is not directly related to teaching / 
learning but rather to the interest of potential employers who expect graduates to master certain programming languages and environments.

\section{METHODOLOGY}

In the website of the Directorate General of Higher Education (DGES) [1] the various courses accredited in Portugal are listed. The research can be done by institution, course, district, type of education (polytechnic or university), type of establishment (public, private, military), area (education, arts and others) and type of course and others). In the case of the present study the research by the Area: Sciences, mathematics and computer science returned 675 Courses, 121 Institutions. In this research appear courses such as biology that falls outside the scope of this document. The DGES website also allows you to consult the guides of the entrance exams. The research can be done based on Area / Course, Course / Institution, District / Institution and Institution / Course. The choice was made from the Area of Technologies and links were returned to information on 193 courses. We extracted course that in its denomination had the content comput * and informát *. We also added eight that seemed relevant to us as Management and Information Systems or information technologies. The basis of our study consists of a course of 66 different intuitions.

Of these 122 courses: 106 Lic- $1^{\circ}$ cycle, 15 Integrated Masters and 1 Prep. MI.

10 of Polytechnic Private Higher Education, 17 University Private Higher Education, 51 Polytechnic Public Higher Education, 43 University Public Higher Education and 1 University Higher Education.

We found 63 different institutions and 56 different denominations of courses, being the most frequent computer engineering.

In Portugal the entrance tests are defined by the institutions, as well as their respective weight in the average admission, being 1 Mathematics, 1707 Physics and Chemistry 16 Mathematics, 1707 Physics and Chemistry Mathematics A, 40 Choice of sets: as 19 Mathematics A, 07 Physics and Chemistry 19 Mathematics or 19 Mathematics A and 18 Portuguese or 02 Biology and Geology or 16 Mathematics or 10 Descriptive Geometry 16 Mathematics and 10 Choose from several as 04 Economy 09 Geography 16 Mathematics 18 English 19 Mathematics A.

The number of places was 6324 in the first phase and 795 in the second phase.

Placements of private education are not provided.

The course that had the highest average of the last placed in the first phase was computer engineering of FEUP, Faculty of Engineering of the University of Porto (178 points in 200).

Only 59 courses filled all the vacancies (we cannot count on information from private institutions). The following section will focus only on these 59 courses.

\section{COURSES THAT FILL THE VACANCIES: UCS AND PROGRAMMING LANGUAGES, TWO FIRST SEMESTERS.}

The 59 courses that filled the vacancies have different types of denominations, being once more Computer Engineering the most frequent (33 in 59). These 59 are from 30 different higher education institutions, and the University of Minho has 6 of these courses.

We analyze the curricular plan of these 59 courses. Of these, only 46 are available on-line. In this case, we have to use $\mathrm{C}++, \mathrm{C}++$, Haskell, $\mathrm{C}++$, Excel $+\mathrm{C}$, 10 Java, 1 Python, 1 Python $+\mathrm{HTML}+$ Java, 1 Python + Java, 1 Scheme + $\mathrm{C}++, 2$ Scheme + Java, and $1 \mathrm{XML}+$ java. Of these, 4 had only 1 UC of programming in the first year, 29 2, 63,54 and 25.

\section{ANALYSIS OF THE 10 COURSES WITH THE LARGEST NUMBER OF PLACES}

The 46 courses that we present in the previous section will be analyzed 10. The choice of these and not others is related to the number of places is superior to the other courses.

\subsection{Mestrado integrado Engenharia Informática, Universidade Nova de Lisboa - Faculdade de Ciências e Tecnologia}

In this course there are 210 credits (ECTS) compulsory and 90 ECTS optional, 153 and 75, respectively belong to the area of computer science. In the following table we can see the semester, denomination, ECTS and which the programming language that the curricular units use according to what is written in their discipline sheet.

Table 1. PLs, ECTS and unit names, Mestrado Integrado, Engenharia Informática, FCT@UNL [2]. 


\begin{tabular}{c|l|c|l}
\hline \hline Semes & Name & ECTs & LP \\
\hline 1 & Introduction to Programming & 9 & java \\
\hline 2 & Computer Architecture & 9 & C e assmbley \\
\hline 2 & Object Oriented Programming & 9 & Java \\
\hline 3 & Algorithms and data structures & 9 & Java \\
\hline 3 & Fundamentals of Operating Systems & 9 & C \\
\hline 3 & Computational Logic & 6 & Tarski, Fitch e Boole \\
\hline 4 & Data base & 9 & SQL, XML \\
\hline 4 & Languages and Programming Environments & 6 & C, OCalm, JKavascript \\
\hline 5 & Computer Graphics and Interfaces & 6 & Javascript, C/C++ ou \\
\hline 5 & Artificial intelligence & 6 & Prolog \\
\hline Op5 & Competition and Parallelism & 6 & java e C \\
\hline Op5 & Representation of Knowledge and Systems of Reasoning & 6 & Ontology Languages \\
\hline Op6 & Software Construction and Verification & 6 & java \\
\hline
\end{tabular}

\subsection{Licenciatura em Engenharia Informática, ISEP}

In this course there are 180 credits (ECTS) compulsory, 52 and 63, respectively belong to the areas Basic Informatics and Specialty Sciences / Technologies / Informatics Engineering [3] [4]. In the following table we can see the semester, denomination, ECTS and which the programming language that the curricular units use according to what is written in their discipline sheet.

Table 2. PLs, ECTS and unit names, Lic. Eng ${ }^{a}$ Informática, ISEP [4].

\begin{tabular}{l|l|l|l}
\hline \hline Semester & Name & ECTS & PLs \\
\hline 1 & Algorithm and Programming & 6 & Java \\
\hline 2 & Programming Paradigms & 6 & java \\
\hline 4 & Languages and Programming & 6 & XML \\
\hline 5 & Advanced Algorithm & 5 & $\begin{array}{l}\text { Paradigma da Programação } \\
\text { em Lógica. }\end{array}$ \\
\hline
\end{tabular}

\subsection{Mestrado integrado, Engenharia Informática, Universidade do Minho}

In this course there are 300 credits (ECTS) compulsory, 60 and 140 respectively belong to the areas Basic Informatics Informatics Engineering [5] [6]. In the following table we can see the semester, denomination, ECTS and which the programming language that the curricular units use according to what is written in their discipline sheet.

Table 3 PLs, ECTS and unit names, Lic. Enga Informática, UMinho [6].

\begin{tabular}{r|l|c|c}
\hline \hline Sem & Name & ECTS & Pls \\
\hline 1 & Functional Programming & 5 & HaskelI \\
\hline 1 & Computer Labs I & 5 & Haskell \\
\hline 2 & Imperative Programming & 5 & $\mathrm{C}$ \\
\hline 2 & Computer Laboratories II & 5 & $\mathrm{C}$ \\
\hline
\end{tabular}




\begin{tabular}{r|l|c|c}
\hline \hline 3 & Algorithms and Complexity & 5 & C \\
\hline 4 & Object Oriented Programming & 5 & java \\
\hline 4 & Computer Labs III & 5 & C+java \\
\hline
\end{tabular}

\subsection{Licenciatura em Engenharia Informática e de Computadores, Instituto Superior Técnico}

In this course there are 180 credits (ECTS) compulsory, 12, 12 and 40,5 respectively belong to the areas Computer Graphics and Multimedia, Logic and Computation and Methodology and Technology of Programming. In the following table we can see the semester, denomination, ECTS and which the programming language that the curricular units use according to what is written in their discipline sheet.

Table 4. PLs, ECTS and unit names, Licenciatura em Engenharia Informática e de Computadores, IST [7]

\begin{tabular}{c|l|l|r}
\hline \hline Sem & UC & LP & ECTS \\
\hline 1 & Fundamentals of Programming & Python & 7,5 \\
\hline 2 & Introduction to Algorithms and Data Structures & C & 7,5 \\
\hline 3 & Programming with Objects & java & 6 \\
\hline 5 & CG & java & 4,5 \\
\hline 5 & Artificial intelligence & Lisp & 7,5
\end{tabular}

\subsection{Licenciatura em Engenharia Informática, Universidade de Coimbra}

In this course there are 180 credits (ECTS) compulsory, 138 belong to the area Computer science [8] [9]. In the following table we can see the semester, denomination, ECTS and which the programming language that the curricular units use according to what is written in their discipline sheet.

Table 5. PLs, ECTS and unit names, Licenciatura em Engenharia Informática, Universidade de Coimbra [8] [9].

\begin{tabular}{c|l|c|l}
\hline \hline Sem & UC & ECTS & PLs \\
\hline 1 & Introduction to Programming and & 6 & Python \\
\hline 2 & Computer Architecture & 6 & C \\
\hline 2 & Principles of Procedural Programming & 6 & C \\
\hline 3 & Introduction to Communication & 6 & C \\
\hline 3 & Object Oriented Programming & 6 & java \\
\hline 4 & Algorithms and data structures & 6 & C \\
\hline 4 & Multimedia & 6 & ActionScript 3.0 \\
\hline 6 & CG & 6 & C \\
\hline
\end{tabular}

\subsection{Licenciatura em Engenharia Informática e de Computadores, Instituto Superior de Engenharia de Lisboa}

In this course there are 144 credits (ECTS) compulsory and 24 ECTS optional, 114 and 18 to 30 , respectively belong to the area of computer science engineering [10]. In the following table we can see the semester, denomination, ECTS and which the programming language that the curricular units use according to what is written in their discipline sheet.

Table 6. PLs, ECTS and unit names,, Licenciatura em Engenharia Informática, ISEL [10].

\begin{tabular}{c|l|r|l}
\hline \hline Sem & UC & ECTS & LP \\
\hline 1 & Programming [required] & 6 & java \\
\hline
\end{tabular}




\begin{tabular}{r|l|r|l}
\hline \hline 2 & Object Oriented Programming [required] & 6 & java \\
\hline 3 & $\begin{array}{l}\text { Programming in Computing Systems } \\
\text { [mandatory] }\end{array}$ & 6 & \\
\hline 3 & Logic and Computation [optional] & 6 & Prolog \\
\hline 3 & Functional Programming [optional] & 6 & $\begin{array}{l}\text { Haskell e } \\
\text { lisp }\end{array}$ \\
\hline 4 & Operating Systems [required] & 6 & $\mathrm{C}$ \\
\hline 4 & Modeling and Design Patterns [optional] & 6 & java \\
\hline 5 & Competitive Programming [mandatory] & 6 & java \\
\hline 5 & Internet Programming [required] & 6 & JavaScript \\
\hline 5 & Embedded Systems I [optional] & 6 & $\mathrm{C}$ \\
\hline 5 & Compilers [optional] & 6 & java \\
\hline
\end{tabular}

\subsection{Mestrado Integrado em Engenharia Informática e Computação, Faculdade de Engenharia da Universidade do Porto}

In this course there are 258 credits (ECTS) compulsory, 37,5 belong to the area programing, 18 to Computer Architecture and 12 to Fundamentals of Programming [11] [12]. In the following table we can see the semester, denomination, ECTS and which the programming language that the curricular units use according to what is written in their discipline sheet.

Table 7. PLs, ECTS and unit names, Mestrado Integrado em Engenharia Informática, FEUP [11] [12].

\begin{tabular}{r|l|r|c}
\hline \hline Sem & \multicolumn{1}{|c|}{ IC } & ECTs & PLs \\
\hline 1 & Fundamentals of Programming & 6 & Scheme \\
\hline 2 & Programming & 7,5 & $\mathrm{C}$ \\
\hline 3 & Algorithms and data structures & 7,5 & $\mathrm{C}$ \\
\hline 3 & Computer Laboratory & 6 & $\mathrm{C}$ \\
\hline 4 & Conception and Analysis of Algorithms & 6 & $\mathrm{C}$ \\
\hline 4 & CG & 6 & $\mathrm{C}$ \\
\hline 4 & Object Oriented Programming Lab & 6 & java \\
\hline 5 & Logic Programming & 4,5 & prolog \\
\hline 5 & Languages and Web Technologies & 6 & javascript \\
\hline 6 & Artificial intelligence & 6 & prolog \\
\hline 6 & Compilers & 6 & java e C \\
\hline 6 & Distributed systems & 6 & C \\
\hline
\end{tabular}




\subsection{Licenciatura em Engenharia Informática, Faculdade de Ciências da Universidade de Lisboa}

In this course there are 168 credits (ECTS) compulsory, 114 belong to the area Computer Science and Engineering [13] [14]. In the following table we can see the semester, denomination, ECTS and which the programming language that the curricular units use according to what is written in their discipline sheet.

Table 8. PLs, ECTS and unit names, licenciatura em Engenharia Informática, Faculdade de Ciências da Universidade de Lisboa. [14]

\begin{tabular}{r|l|r|l}
\hline \hline Sem & UC & ECTS & PLs \\
\hline 1 & Introduction to Programming & 6 & java \\
\hline 2 & Algorithms and data structures & 6 & java \\
\hline 2 & Programming Laboratories & 6 & java \\
\hline 3 & Principles of Programming & 6 & Haskell \\
\hline 4 & Object-Centered Development & 6 & java \\
\hline 5 & Introduction to Artificial Intelligence & 6 & Prolog \\
\hline 6 & Construction of Software Systems & 6 & java \\
\hline
\end{tabular}

\subsection{Licenciatura em Engenharia Informática, Universidade de Aveiro}

In this course there are 180 credits (ECTS) compulsory, 30 belong to the area Computer Science, 18 Informatics / Architecture of Computational Systems and 42 to Computer Science / Programming Technology [15] [16]. In the following table we can see the semester, denomination, ECTS and which the programming language that the curricular units use according to what is written in their discipline sheet.

Table 9. PLs, ECTS and unit names Licenciatura em Engenharia Informática, Universidade de Aveiro. [15] [16]

\begin{tabular}{c|c|c|c}
\hline \hline Sem & UC & ECTS & LP \\
\hline 1 & Proarammina fundamentals & 6 & Python \\
\hline 1 & Introduction to Web Technoloaies & 6 & JavaScript \\
\hline 2 & Obiect Oriented Proarammina & 6 & Java \\
\hline 3 & Operatina Svstems & 6 & iava \\
\hline 4 & Distributed Computina & 6 & iava \\
\hline
\end{tabular}

\subsection{Licenciatura em Engenharia Informática, Universidade da Beira Interior}

In this course there are 180 credits (ECTS) compulsory, 138 belong to the area Computer Science [17] [18]. In the following table we can see the semester, denomination, ECTS and which the programming language that the curricular units use according to what is written in their discipline sheet.

Table 10. PLs, ECTS and unit names Licenciatura em Engenharia Informática, Universidade da Beira Interior [18]. 


\begin{tabular}{c|c|c|c}
\hline Sem & UC & ECTS & LPS \\
\hline 1 & Web Composition & 6 & HTML \\
\hline 1 & Programming I & 6 & C \\
\hline 2 & Computer Architecture II & 6 & Assembly x86 \\
\hline 2 & Programming II & 6 & C \\
\hline 3 & Algorithms and data & & C \\
\hline 3 & structures & 6 & java \\
\hline 4 & $\begin{array}{c}\text { Object Oriented } \\
\text { Programming }\end{array}$ & 6 & \\
\hline 6 & Data base & 6 & C \\
\hline
\end{tabular}

\subsection{Licenciatura em Engenharia Informática, Universidade de Trás -os -Montes e Alto Douro}

In this course there are 180 credits (ECTS) compulsory, 88 belong to the area Computer Science and 5 optional [19] [20]. In the following table we can see the semester, denomination, ECTS and which the programming language that the curricular units use according to what is written in their discipline sheet.

Table 11. PLs, ECTS and unit names Licenciatura em Engenharia Informática, Universidade de Trás os -Montes e Alto Douro. [20]

\begin{tabular}{c|l|c|c}
\hline \hline Sem & \multicolumn{1}{|c|}{ UC } & ECTS & LP \\
\hline 2 & Computer architecture & 6 & C \\
\hline 3 & $\begin{array}{l}\text { Methodologies of } \\
\text { Programming II }\end{array}$ & 6 & C \\
\hline 4 & Algorithm & 6 & C \\
\hline 4 & $\begin{array}{l}\text { Programming methodologies } \\
\text { III }\end{array}$ & 6 & C \\
\hline 5 & Methodologies of & 6 & ASP.NET \\
\hline
\end{tabular}




\section{CONCLUSÕES}

With this study we realized that the courses related to computer science in Portugal are very different from each other: they differ greatly in the percentage of ects with programming languages, but also in the languages taught and in the programming environments used.

It would be interesting to see if this is also different in other countries.

\section{REFERENCES}

[1] Direção-Geral do Ensino Superior, "DGES," 2018. [Online]. Available: http://www.dges.gov.pt/. [Acedido em 13 jun 2018].

[2] Universidade Nova de Lisboa, “Computer Science and Engineering@UNL," 2015. [Online]. Available: http://www.unl.pt/guia//2017/fct/UNLGI_getCurso?curso=935.

[3] Diario da Republica, "DRE," 06 Fev 2015. [Online]. Available: https://www.scribd.com/document/260794920/Diario-da-Republica-n-\%C2\%BA-40-2015. [Acedido em 2018].

[4] ISEP, "Engenharia Informática," 2018.2 Anailable: https://www.isep.ipp.pt/Course/Course/26.

[5] Diário da República, "DRE," 10 Agosto 2015. [Online]. Available: https://dre.pt/application/conteudo/69976284. [Acedido em 2018].

[6] UMinho, "Engenharia Informática," 2018.2 [Online]. Available: http://miei.di.uminho.pt/plano_estudos.html.

[7] Diario da República, “DRE," 29 Set 2015. [Online]. Available: https://dre.pt/application/conteudo/70402793.

[8] IST, "Licenciatura Bolonha em Engenharia Informática e de Computadores - Alameda," 2018. [Online]. Available: https://fenix.tecnico.ulisboa.pt/cursos/leic-a/paginas-de-disciplinas.

[9] Universidade de Coimbra, "Licenciatura em Engenharia Informática," 2018. [Online]. Available: https://apps.uc.pt/courses/PT/programme/362/2018-2019?id_branch=669.

[1 Instituto superior de engenharia de Lisboa, "ENGENHARIA INFORMÁTICA E DE

O] COMPUTADORES," 2018. [Online]. Available: https://www.isel.pt/cursos/licenciaturas/engenhariainformatica-e-computadores/plano-curricular.

[1 Diario da Republica, "DRE," 21 Ab 2005. [Online]. Available:

1] https://dre.pt/application/conteudo/67040186.

[1 FAculdade de Engenharia da Universidade do Porto, "Mestrado Integrado em Engenharia

2] Informática e Computação," 2018.2 [Online]. Available: https://sigarra.up.pt/feup/pt/cur_geral.cur_planos_estudos_view?pv_plano_id=2496\&pv_ano_lectivo =2017\&pv_tipo_cur_sigla=MI\&pv_origem=CUR.

[1 Diario da Republica, "DRE," 29 Set 2016. [Online]. Available:

3] https://dre.pt/application/conteudo/75436691. 
[1 Faculdade de Ciencias da Universidade de Lisboa, "Licenciatura em Engenharia Informática," 2018.

4] [Online]. Available: https://fenix.ciencias.ulisboa.pt/degrees/engenharia-informatica564500436615278/descricao.

[1 Diário da República, "DRE," 7 Maio 2014. [Online]. Available:

5] https://dre.pt/application/conteudo/25711307.

[1 Universidade de Aveiro, "Licenciatura em Engenharia Informática," 2018. [Online]. Available: 6] https://www.ua.pt/ensino/course/383/?p=4.

[1 Diario da Republica, "DRE," 19 Set 2014. [Online]. Available: https://dre.pt/application/file/57118556. 7]

[1 Universidade Beira Interior, "Engenharia Informática - 1o Ciclo," 2018. [Online]. Available: 8] http://www.ubi.pt/PlanoDeEstudos/42/1408/2018.

[1 Diario da Republica, "DRE," 20 Out 2011. [Online]. Available: 9] https://dre.pt/application/file/a/2472913.

[2 UTAD, "licenciatura em Enhenharia Informática," 2018. [Online]. Available: o] http://side.utad.pt/cursos/einformatica/disciplinas/paginas/. 